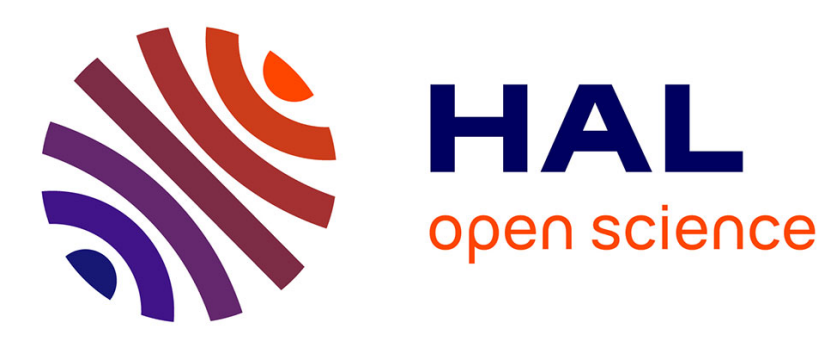

\title{
Specific obstetrical risk factors for urinary versus anal incontinence 4years after first delivery.
}

Xavier Fritel, Babak Khoshnood, Arnaud Fauconnier

\section{To cite this version:}

Xavier Fritel, Babak Khoshnood, Arnaud Fauconnier. Specific obstetrical risk factors for urinary versus anal incontinence 4years after first delivery.. Progrès en Urologie, 2013, 23 (11), pp.911-6. 10.1016/j.purol.2013.06.009 . inserm-00870500

\section{HAL Id: inserm-00870500 https://www.hal.inserm.fr/inserm-00870500}

Submitted on 7 Oct 2013

HAL is a multi-disciplinary open access archive for the deposit and dissemination of scientific research documents, whether they are published or not. The documents may come from teaching and research institutions in France or abroad, or from public or private research centers.
L'archive ouverte pluridisciplinaire HAL, est destinée au dépôt et à la diffusion de documents scientifiques de niveau recherche, publiés ou non, émanant des établissements d'enseignement et de recherche français ou étrangers, des laboratoires publics ou privés. 
1 Specific obstetrical risk factors for urinary versus anal incontinence four years after first

2 delivery.

\section{Abstract}

4 Aim: delivery can be complicated by urinary or anal incontinence (UI or AI). We

5 hypothesized that the mechanisms of injury may differ for UI and AI. Hence, obstetrical risk

6 factors may be specific for different types of incontinence.

7 Design: Data on maternal characteristics were collected at first delivery. Data on incontinence

8 were obtained by a questionnaire completed by 627 women four years after first delivery. UI

9 was defined by "Do you have involuntary loss of urine" and AI by "Do you have involuntary

10 loss of flatus or stool". A multinomial logistic regression analysis was conducted to assess

11 risk factors for UI only, AI only, and UI + AI.

12 Results: $22 \%$ of women reported UI only, $6.5 \%$ AI only, and $6.5 \%$ both. Risk factors

13 associated with UI only were age (at $1^{\text {st }}$ delivery) $\geq 30$ (OR 2.27 [95\% CI 1.47-3.49]), pre-

14 existing UI (6.44 [2.19-19.0]) and pregnancy UI (3.64 [2.25-5.91]). Risk factors associated

15 with AI only were length of the second active stage > 20 minutes (2.86 [1.15-7.13]) and third

16 degree perineal tear (20.9 [1.73-252]). Significant predictors of UI+AI were age $\geq 30(2.65$

17 [1.29-5.46]), no epidural (4.29 [1.65-11.1]), third degree perineal tear (20.0 [1.28-314]), and

18 UI before pregnancy (32.9 [9.00-120]). Cesarean delivery was not significantly associated

19 with UI, AI, or UI+AI, although for all three outcomes, the adjusted odds ratios were

20 substantially less than one.

21 Conclusion: We found specific associations between obstetrical risk factors and urinary

22 versus anal incontinence four years after first delivery. Our results are consistent with the

23 hypothesis that the underlying mechanisms of injury differ for UI and AI.

25 Key-words: urinary incontinence; anal incontinence; delivery

26 Word count: abstract 261; text 1996. 
Facteurs de risque obstétricaux spécifiques de l'incontinence urinaire ou de l'incontinence anale quatre ans après le premier accouchement.

\section{Résumé}

Objectif : L'accouchement peut se compliquer par une incontinence urinaire ou anale (IU ou IA). Notre hypothèse est que si les mécanismes lésionnels sont différents pour chaque incontinence, les facteurs de risque obstétricaux devraient être spécifiques à chaque type d'incontinence.

Méthodes : Les données sur la mère ont été recueillies à la première naissance. Les données sur l'incontinence ont été obtenues par un questionnaire rempli par 627 femmes, quatre ans après le premier accouchement. L'IU était définie par « Avez-vous des fuites involontaires d'urine » et l'IA par « Avez-vous des pertes involontaires de gaz ou de selles ». Une régression logistique multinomiale a été conduite afin d'estimer les facteurs de risque pour l'IU isolée, l'IA isolée, et IU+IA.

Résultats : 22\% des femmes avaient une IU isolée, 6,5\% une IA isolée, et 6,5\% les deux à la fois. Les facteurs de risque associés à l'IU isolée étaient un âge (au 1er accouchement) $\geq 30$ ans (OR 2,27 [IC 95\% 1,47-3,49]), une IU préexistante $(6,44$ [2,19-19,0]), et une IU de la grossesse $(3,64$ [2,25-5,91]). Les facteurs de risque associés à l'IA isolée étaient une durée des efforts expulsifs > 20 minutes $(2,86$ [1,15-7,13]) et un périnée complet (20,0 [1,28-314]). Les facteurs de risques pour IU+IA étaient un âge $\geq 30$ ans $(2,65$ [1,29-5,46]), 1'absence de péridurale $(4,29$ [1,65-11,1]), un périnée complet $(20,0$ [1,28-314]), et une IU préexistante à la grossesse (32,9 [9,00-120]). L'accouchement par césarienne n'était pas significativement associée à l'IU isolée, à IA isolée, ou IU+IA, bien que pour les trois, les OR ajustés étaient sensiblement inférieur à un.

Conclusion : Nous avons trouvé des associations spécifiques entre des facteurs obstétricaux et l'incontinence urinaire ou anale quatre ans après le premier accouchement. Nos résultats sont compatibles avec l'hypothèse que les mécanismes lésionnels diffèrent pour l'IU et l'IA.

Mots-clés: incontinence urinaire ; incontinence anale ; accouchement 


\section{Introduction}

First childbirth may become complicated by urinary or anal incontinence (UI or AI). The exact pathophysiology of postnatal incontinence is not well understood. Observable lesions such as third degree perineal tears can explain anal incontinence but this occurs in only a minority of deliveries. Other occult injury to the pelvic floor, e.g., pudendal neuropathy or levator ani muscle avulsion could affect urinary or anal continence. ${ }^{1}$ The pudendal nerve innervates striated muscles of the pelvic floor, including levator ani, urethral sphincter and anal sphincter. Risk factors for pudendal nerve damage during childbirth are birth weight $>4$ $\mathrm{kg}$ and a second active stage longer than 30 minutes. $^{2}$ The levator ani muscle which is involved in the maintenance of the urinary and anal continence can also be injured at the time of childbirth. Using MRI findings, DeLancey reported injuries of the levator ani in $20 \%$ of primiparous women and Dietz found lesions in $36 \%$ of women using sonography. ${ }^{3,4}$ Risk factors for the lesions of the levator ani during childbirth are advanced maternal age, forceps delivery and the duration of the second stage. ${ }^{5}$ The two sphincteric (urinary and anal) complexes are also bound by crossed reflex like the vesico-anal reflex. ${ }^{6}$

Previous literature has not elucidated to what extent postnatal urinary incontinence and postnatal anal incontinence result from the same underlying mechanisms of injury. The analysis of risk factors associated with postnatal incontinence suggests that certain risk factors such as advanced maternal age and parity may be common to both UI and AI. ${ }^{7,8}$ Other risk factors may be more specifically associated with one type of incontinence. For example, UI during pregnancy has been found to be a specific risk factor for postnatal UI and instrumental vaginal childbirth for postnatal AI. ${ }^{9,10}$

We hypothesized that pregnancy and delivery-associated traumatic mechanisms at the origin of postnatal incontinence differ at least to some extent for UI and AI. Therefore, specific obstetrical risk factors are likely to be associated with different types of incontinence. The analysis of risk factors related to stress UI was published previously for a portion of the population. ${ }^{11}$ To complete this objective we performed a secondary analysis in the whole sample of primiparous to identify both risk factors that may be common to UI and AI, and those that may be specifically associated with different types of postnatal incontinence, four years after a $1^{\text {st }}$ delivery. 


\section{Materials and Methods}

89 Our data were initially collected for a study aimed at comparing the risk of incontinence for 90 women delivering in two maternity units. ${ }^{12}$ One maternity had a policy of systematic episiotomy and the other a restrictive policy for episiotomy. The study population includes nulliparous women who delivered a live-born singleton at 37-41 weeks in cephalic presentation in 1996. Mothers whose current mailing address was not known (and those deceased) were excluded. Data on maternal characteristics (age, height, weight), pregnancy (gestational age, epidural, second active stage duration, delivery mode, newborns' birthweight) were collected at the time of childbirth. Women were asked to provide information about pelvic floor disorders using a postal questionnaire, which was sent four years after childbirth. In the absence of response to the first mail, a second and if necessary a third mail was sent. The questionnaire collected data about profession and education level of the mother, interventions on the pelvic floor since childbirth, new pregnancies and pelvic floor symptoms. Urinary incontinence was defined by a positive response (Yes) to the question "Do you have involuntary loss of urine?" and anal incontinence was defined by the answer "Yes" to "Do you have involuntary loss of flatus or stool?" The type of UI was defined using a validated questionnaire (Bristol Female Lower Urinary Tract Symptoms questionnaire), ${ }^{13}$ severity of UI was measured with Sandvik's score, ${ }^{14}$ and AI was assessed using Pescatori's score, ${ }^{15}$ as detailed in a previous publication. ${ }^{12}$ The complete questionnaire used for the study is available online. The choice of cut-off values for continuous variables (maternal age $<30$, BMI $<25 \mathrm{~kg} / \mathrm{m}^{2}$, gestational age $<40$ weeks, active second stage length $>$ 20 minutes, newborn weight $<4000 \mathrm{~g}$ ) was done a priori. We found no evidence of a difference in the risk of urinary incontinence four years after $1^{\text {st }}$ childbirth for women delivering in the two maternity units. However, the risk of anal incontinence was slightly higher for women who delivered in the maternity with a policy of systematic episiotomy. ${ }^{12}$

113 Using data from this enquiry, we first examined risk factors associated with each type of 114 incontinence (UI or AI) using two separate logistic regression models adjusted on maternity. 115 All significant risk factors for UI or AI were then included in a multinomial logit analysis to 116 assess specific risk factors for the following outcomes: UI only, AI only, and UI + AI. 117 Variables for mode of delivery, third degree perineal tear and maternity unit were forced in 118 the model irrespective of their statistical significance in the logistic models. We used estimates of the odds ratios in the multinomial model for each risk factor and outcome in 
120 order to examine the extent to which specific risk factors may be associated with different 121 types of incontinence.

122 We complied with French laws on data confidentiality, and restrictions on type of data 123 collected (e.g. no religious or racial data). Informed consent was obtained from all study 124 participants. 


\section{Results}

127 Among the 1323 primiparous women who met inclusion criteria, postal address was no longer

128

129

130

131

132

133

134

135

136

137

138

139

140

141

142

143

144

145

146

147

148

149

150

151

152

153 valid for $548(41 \%)$ and one had died, $774(59 \%)$ women received the postal questionnaire and $627(81 \%)$ completed it. The first delivery was spontaneous vaginal in 368 cases, instrumental in 209 cases ( 95 by vacuum) and by cesarean section for 50 women. Continence disorders four years after $1^{\text {st }}$ childbirth of the 627 women who responded are summarized in Table 1. The prevalence of UI was $29 \%(\mathrm{~N}=181)$ and that of AI 13\% (82), 22\% of women (140) reported UI only, 6.5\% (41) AI only, and 6.5\% (41) both UI and AI.

Risk factors for UI (with or without AI) were maternal age $\geq 30$ at $1^{\text {st }}$ delivery (adjusted OR, 2.3 [95\% CI 1.5-3.4]), UI before $1^{\text {st }}$ pregnancy (10.2 [3.7-28.1]), and UI during $1^{\text {st }}$ pregnancy (3.3 [2.1-5.1]). Risk factors for AI (with or without UI) were UI before $1^{\text {st }}$ pregnancy (adjusted OR 5.2 [95\% CI 2.3-11.8]), no epidural (versus yes) during $1^{\text {st }}$ delivery (2.4 [1.2$4.8]$ ), second active stage $>20 \min \left(2.5\right.$ [1.2-5.1]), and occurrence of $3^{\text {rd }}$ degree perineal tear during $1^{\text {st }}$ delivery (13.3 [2.1-83.0]). Other factors tested and non-significant were: education level, a BMI greater than $25 \mathrm{~kg} / \mathrm{m}^{2}$, gestational age at first delivery, a first newborn over 4000g, pelvic floor exercises after first delivery, episiotomy at first delivery, a second delivery (this concerns 381 women), and an ongoing pregnancy (see online additional tables $\mathrm{S} 1$ and $\mathrm{S} 2)$.

Table 2 presents the results of the multinomial logistic regression analysis to assess specific risk factors associated with UI only, AI only, and UI+AI. Estimates suggested that different risk factors were associated with the three outcomes. Risk factors associated with UI only were maternal age at delivery $\geq 30$ (adjusted OR 2.3 [95\% CI 1.5-3.5]), pre-existing UI (6.4 [2.2-19.0]) and UI during pregnancy (3.6 [2.2-5.9]), whereas risk factors for AI only were duration of the second active stage $>20 \mathrm{~min}\left(2.9\right.$ [1.1-7.1]), and $3^{\text {rd }}$ degree perineal tear $(20.9$ [1.7-252]). Risk factors significantly associated with UI + AI were maternal age > 30 years (2.6 [1.3-5.5]), UI before pregnancy (32.9 [9.0-120]), no epidural (4.3 [1.6-11.1]) and $3^{\text {rd }}$ degree perineal tear (20.0 [1.3-314]). 


\section{Discussion}

155 To our knowledge, this is one of the few studies that evaluated specific risk factors associated 156 with UI and AI four years after $1^{\text {st }}$ delivery. One previous study, which looked at specific risk 157 factors for UI and AI, was based on data collected six months after first childbirth. ${ }^{16}$ This 158 study found that risk factors were different for postnatal UI (shoulder dystocia and vaginal 159 delivery) vs. postnatal AI (age over 35 years, smoking, duration of the second stage of labor 160 more than an hour and third degree perineal tear).

161 We found that different risk factors were associated with UI only (i.e., without AI), AI only, 162 and UI + AI four years after $1^{\text {st }}$ delivery. Risk factors for UI only were maternal age at $1^{\text {st }}$ 163 delivery $\geq 30$, pre-existing UI and pregnancy UI. Risk factors associated with AI only were 164 length of the second active stage $>20 \mathrm{~min}$ and $3^{\text {rd }}$ degree perineal tear. Risk factors associated with UI + AI were age $\geq 30$, no epidural, $3^{\text {rd }}$ degree perineal tear, and UI before pregnancy.

166 The relatively long period of follow-up in our study (four years after $1^{\text {st }}$ delivery) is an

167 important advantage as the prevalence of postpartum UI tends to decrease spontaneously in 168 the $1^{\text {st }}$ postpartum year. ${ }^{17}$ Nevertheless, our study has certain limitations. The sample size of 169 the study was based on the number of subjects needed to have sufficient power for showing a 170 difference in the outcomes between the two maternities that had different policies for episiotomy in our initial study. ${ }^{12}$ The study was not specifically designed to have sufficient power to explore the specific effects associated with different risk factors. Indeed, the confidence intervals for the estimates of the effects for several risk factors were wide and lack of sufficient power may explain the absence of statistically significant results for some of the risk factors in the present study. In particular, the lack of statistical significance for the associations between mode of delivery and outcomes (different types of incontinence) is likely to be due to insufficient power. It is worth noting that the point estimates (odds ratios) suggested a lower, albeit not statistically significant, risk for all three outcomes (UI only, AI only and UI+AI) for women who delivered following a cesarean section. For reasons of statistical power we also renounced conduct an analysis based on the type of instrument used for delivery (forceps or vacuum).

182 Our findings of specific associations between obstetric risk factors and prevalence of UI only, 183 AI only and UI+AI may be due to differences in the underlying mechanisms of injury for 184 different types of incontinence. The two main mechanisms proposed to explain postnatal AI are sphincter injury and pudendal neuropathy. In our study, the specific risk factors for AI 
186 (third degree perineal tear and prolonged second active stage) are compatible with these 187 mechanisms. Prolonged active second stage is associated with pudendal nerve damage. ${ }^{2}$ Even 188 following repair, $3^{\text {rd }}$ degree perineal tear is associated with anal incontinence years after delivery. ${ }^{18}$

190 Concerning postnatal stress urinary incontinence, the mechanisms of injury are still largely

191 unknown. ${ }^{17}$ Vaginal birth is likely to increase the mobility of the urethra or to be accompanied 192 by lesions of the levator ani. ${ }^{3,4}$ However, urethra mobility returns to prenatal values a few 193 months after delivery. ${ }^{19}$ Wijma et al. found no relation between urethra mobility and postnatal $194 \mathrm{UI}^{20}$ Dietz and Lanzarone found no link between levator ani avulsion and postnatal stress 195 UI. ${ }^{4}$ DeLancey et al. reported that only $16 \%$ of postnatal stress UI could be explained by 196 urethra mobility, whereas urethra closing pressure could account for $25 \%$ of postnatal de novo 197 stress UI. ${ }^{21}$ The relation between urethra closure pressure and pregnancy remains unclear. 198 Iosif et al. found closure pressure to increase during pregnancy and to decrease after delivery, 199 while Le Coutour et al. reported opposite findings. ${ }^{22,23}$ In our study, the finding of an 200 association between maternal age and UI could be explained by a lower urethra closure 201 pressure as the latter is known to decrease with increasing maternal age. ${ }^{24} \mathrm{We}$ are not aware 202 of any studies that have examined the link between pregnancy UI and urethra closure pressure 203 or urethral mobility. ${ }^{17}$

204 In conclusion, our results suggest that urinary incontinence and anal incontinence four years 205 after $1^{\text {st }}$ delivery do not share the same set of risk factors. These results are consistent with the 206 hypothesis that the underlying mechanisms of postnatal incontinence differ for urinary versus 207 anal incontinence. This implies in turn that different strategies may be needed for prevention 208 of urinary and anal incontinence. 
1 Billecocq S, Morel MP, Fritel X. Traumatisme du levator ani après l'accouchement, de l'étirement à l'avulsion : revue de la littérature [levator ani trauma after childbirth, from stretch injury to avulsion: review of the literature]. Prog Urol 2013;23:511-8.

2 Sultan AH, Kamm MA, Hudson CN. Pudendal nerve damage during labour: prospective study before and after childbirth. BJOG 1994;101:22-8.

3 DeLancey JO, Kearney R, Chou Q, Speights S, Binno S. The appearance of levator ani muscle abnormalities in magnetic resonance images after vaginal delivery. Obstet Gynecol 2003;101:46-53. Dietz HP, Lanzarone V. Levator trauma after vaginal delivery. Obstet Gynecol 2005;106:707-12. Kearney R, Miller JM, Ashton-Miller JA, DeLancey JOL. Obstetric factors associated with levator ani muscle injury after vaginal birth. Obstet Gynecol 2006;107:144-9. Basinski C, Fuller E, Brizendine EJ, Benson JT. Bladder-anal reflex. Neurourol Urodyn 2003;22:683-6. Rortveit G, Hannestad YS, Daltveit AK, Hunskaar S. Age- and type-dependent effects of parity on urinary incontinence: The Norwegian EPINCONT Study. Obstet Gynecol 2001;98:1004-10. Abramov Y, Sand PK, Botros SM, Gandhi S, Miller JJR, Nickolov A, Goldberg RP. Risk factors for female anal incontinence: new insight through the Evanston-Northwestern twin sisters study. Obstet Gynecol 2005;106:726-32. van Brummen HJ, Bruinse HW, van de Pol G, Heintz AP, van der Vaart CH. The effect of vaginal and cesarean delivery on lower urinary tract symptoms: what makes the difference? Int Urogynecol J 2007;18: 133-9.

10 MacArthur C, Bick DE, Keighley MRB. Faecal incontinence after childbirth. BJOG 1997;104:46-50.

11 Fritel X, Fauconnier A, Levet C, Bénifla JL. Stress urinary incontinence four years after the first delivery: a retrospective cohort study. Acta Obstet Gynecol Scand 2004;83:941-5.

Fritel X, Schaal JP, Fauconnier A, Bertrand V, Levet C, Pigné A. Pelvic floor disorders 4 years after first delivery, a comparative study of restrictive versus systematic episiotomy. BJOG 2008;115:247-52. Jackson S, Donovan J, Brookes S, Eckford S, Swithinbank L, Abrams P. The Bristol Female Lower Urinary Tract Symptoms questionnaire: development and psychometric testing. Br J Urol 1996;77:80512.

Sandvik H, Seim A, Vanvik A, Hunskaar S, Sandvik A. Severity index for epidemiological surveys of female urinary incontinence: comparison with 48-hour pad-weighing tests. Neurourol Urodyn 2000;19:137-45. 
16 Hatem M, Pasquier JC, Fraser W, Lepire E. Factors associated with postpartum urinary/anal incontinence in primiparous women in Quebec. J Obstet Gynaecol Can 2007;29:232-9.

17 Fritel X, Ringa V, Quiboeuf E, Fauconnier A. Female urinary incontinence, from pregnancy to menopause, a review of epidemiologic and pathophysiologic findings. Acta Obstet Gynecol Scand 2012;91:901-10.

18 Mous M, Muller SA, de Leeuw JW. Lonf-term effects of anal sphincter rupture during vaginal delivery: faecal incontinence and sexual complaints. BJOG 2008;115:234-8.

19 Toozs-Hobson P, Balmforth J, Cardozo L, Khullar V, Athanasiou S. The effect of mode of delivery on pelvic floor functional anatomy. Int Urogynecol J Pelvic Floor Dysfunct 2008;19:407-16.

20 Wijma J, Potters AE, de Wolf BT, Tinga DJ, Aarnoudse JG. Anatomical and functional changes in the lower urinary tract following spontaneous vaginal delivery. BJOG 2003;110:658-63.

21 DeLancey JO, Miller JM, Kearney R, Howard D, Reddy P, Umek W, Guire KE, Margulies RU, Ashton-Miller JA. Vaginal birth and de novo stress incontinence: relative contributions of urethral dysfunction and mobility. Obstet Gynecol 2007;110:354-62.

22 Iosif S, Ingemarsson I, Ulmsten U. Urodynamic studies in normal pregnancy and in puerperium. Am J Obstet Gynecol 1980;137:696-700.

23 Le Coutour X, Jouffroy C, Beuscart R, Renaud R. Influence de la grossesse et de l'accouchement sur la fonction de clôture cervico-urétrale [Effect of pregnancy and delivery on the function of the cervicourethral closure]. J Gynecol Obstet Biol Reprod 1984;13:771-4.

24 Edwards L, Malvern J. The urethral pressure profile: Theoretical considerations and clinical application. Br J Urol 1974;46:325-36. 


\section{Table 1}

Continence complaints 4 years after $1^{\text {st }}$ childbirth. Where percentages do not add to $100 \%$, there were some missing data (from 0 to $3.3 \%$ ).

Troubles de la continence 4 ans après le premier accouchement. Quand la somme des pourcentages est inférieure à $100 \%$ c'est le signe de quelques données manquantes (de 0 à $3,3 \%)$.

\begin{tabular}{llr}
\hline Continence troubles 4 years after $1^{\text {st }}$ childbirth & $\mathrm{n}(\%)$ \\
\hline & $\mathrm{N}=627$ & $438(71)$ \\
\hline Urinary Incontinence (UI) & no & $181(29)$ \\
& yes & $438(71)$ \\
Severity of UI & no UI & $110(18)$ \\
(Sandvik score) & slight & $42(7)$ \\
& Moderate & $16(3)$ \\
& Severe & $55(30)$ \\
Type of UI & stress & $12(7)$ \\
(\% among women with UI) & urgency & $109(60)$ \\
& mixed & $24(13)$ \\
UI bothersome & Not a problem & $107(59)$ \\
(\% among women with UI) & A bit of a problem & $27(15)$ \\
& Quite a problem & $17(9)$ \\
& A serious problem & $525(84)$ \\
Anal Incontinence (AI) & no & $82(13)$ \\
& yes & $64(78)$ \\
Type of AI & Flatus only & $18(22)$ \\
(\% among women with AI) & Stool & $1(1)$ \\
AI bothersome & Not a problem & $36(44)$ \\
(\% among women with AI) & A bit of a problem & $13(16)$ \\
& Quite a problem & $30(37)$ \\
& A serious problem & \\
\hline & &
\end{tabular}




\section{Table 2}

Risk factors for urinary incontinence (UI) only, anal incontinence (AI) only, and UI+AI. Multinomial logistic regression adjusted on maternity. Other factors tested and non-significant were: education level, a BMI greater than $25 \mathrm{~kg} / \mathrm{m}^{2}$, gestational age at first delivery, a first newborn over $4000 \mathrm{~g}$, pelvic floor exercises after first delivery, episiotomy at first delivery, a second delivery, and an ongoing pregnancy. Case numbers may not add up because of some missing data for given risk factors (from 0 to $4.6 \%$ ).

Facteurs de risque d'incontinence urinaire (IU) isolée, d'incontinence anale (IA) isolée, et d'IU+IA. Régression logistique multinomiale ajusté sur la maternité. Les autres facteurs testés et non-significatifs sont les suivants : le niveau scolaire, un BMI supérieur à $25 \mathrm{~kg} / \mathrm{m}^{2}$, l'âge gestationnel au premier accouchement, un premier enfant de plus de 4000g, une rééducation périnéale après le premier accouchement, un nouvel accouchement, et une grossesse en cours. Le nombre de sujet peut être inférieur à ce qui est attendu en raison de données manquantes pour certains facteurs de risque (de 0 à 4,6\%).

\begin{tabular}{|c|c|c|c|c|c|}
\hline Variable & & $(\mathrm{N})$ & $\begin{array}{l}\text { UI only } \\
\text { adjusted OR } \\
\text { (CI 95\%) }\end{array}$ & $\begin{array}{l}\text { AI only } \\
\text { adjusted OR } \\
\text { (CI 95\%) }\end{array}$ & $\begin{array}{l}\mathrm{IU}+\mathrm{IA} \\
\text { adjusted OR } \\
(\mathrm{CI} 95 \%)\end{array}$ \\
\hline Age at $1^{\text {st }}$ childbirth & $\begin{array}{l}<30 \text { years } \\
\geq 30 \text { years }\end{array}$ & $\begin{array}{l}(415) \\
(212)\end{array}$ & $\begin{array}{l}1 \\
2.27(1.47-3.49)\end{array}$ & $\begin{array}{l}1 \\
1.34(0.65-2.73)\end{array}$ & $\begin{array}{l}1 \\
2.65(1.29-5.46)\end{array}$ \\
\hline UI before pregnancy & $\begin{array}{l}\text { no } \\
\text { yes }\end{array}$ & $\begin{array}{r}(565) \\
(33)\end{array}$ & $\begin{array}{l}1 \\
6.44(2.19-19.0)\end{array}$ & $\begin{array}{l}1 \\
2.02(0.21-18.9)\end{array}$ & $\begin{array}{l}1 \\
32.9(9.00-120)\end{array}$ \\
\hline UI during pregnancy & $\begin{array}{l}\text { no } \\
\text { yes }\end{array}$ & $\begin{array}{l}(468) \\
(133)\end{array}$ & $\begin{array}{l}1 \\
3.64(2.25-5.91)\end{array}$ & $\begin{array}{l}1 \\
1.57(0.64-3.90)\end{array}$ & $\begin{array}{l}1 \\
1.87(0.77-4.55)\end{array}$ \\
\hline Epidural & $\begin{array}{l}\text { no } \\
\text { yes }\end{array}$ & $\begin{array}{l}(101) \\
(526)\end{array}$ & $\begin{array}{l}0.96(0.51-1.78) \\
1\end{array}$ & $\begin{array}{l}1.52(0.59-3.92) \\
1\end{array}$ & $\begin{array}{l}4.29(1.65-11.1) \\
1\end{array}$ \\
\hline Second active stage & $\begin{array}{l}\leq 20 \text { minutes } \\
>20 \text { minutes }\end{array}$ & $\begin{array}{r}(561) \\
(59)\end{array}$ & $\begin{array}{l}1 \\
1.26(0,62-2,57)\end{array}$ & $\begin{array}{l}1 \\
2.86(1.15-7.13)\end{array}$ & $\begin{array}{l}1 \\
2.29(0.73-7.15)\end{array}$ \\
\hline Mode of delivery & $\begin{array}{l}\text { spontaneous } \\
\text { instrumental } \\
\text { cesarean }\end{array}$ & $\begin{array}{r}(368) \\
(209) \\
(50)\end{array}$ & $\begin{array}{l}1 \\
1.16(0.74-1.81) \\
0.54(0.22-1.31)\end{array}$ & $\begin{array}{l}1 \\
1.11(0.54-2.31) \\
0.61(0.14-2.79)\end{array}$ & $\begin{array}{l}1 \\
0.96(0.43-2.11) \\
0.28(0.05-1.70)\end{array}$ \\
\hline Third degree perineal tear & $\begin{array}{l}\text { no } \\
\text { yes }\end{array}$ & $\begin{array}{r}(621) \\
(6)\end{array}$ & $\begin{array}{l}1 \\
3.67(0.22-61.3)\end{array}$ & $\begin{array}{l}1 \\
20.9(1.73-252)\end{array}$ & $\begin{array}{l}1 \\
20.0(1.28-314)\end{array}$ \\
\hline
\end{tabular}

